\title{
Influence of EU-ASEAN health interregionalism on regional health governance
}

\author{
Vincent Rollet ${ }^{1}$
}

Received: 13 April 2016 / Revised: 3 October 2016 / Accepted: 24 October 2016 /

Published online: 3 November 2016

(C) Springer-Verlag Berlin Heidelberg 2016

\begin{abstract}
Over the past decade, remarkable and sustainable progresses have been made in the Association of Southeast Asian Nations (ASEAN) region in the domain of communicable disease control. Nevertheless, communicable diseases remain an important public health issue in the region. In December 2009, within the framework of its Regional Programming for Asia (2007-2013), the European Union (EU) launched a Regional Program on Highly Pathogenic and Emerging Diseases (HPED) in Asia. This 4-year interregional cooperation initiative aimed at enable ASEAN to control zoonoses and to improve pandemic preparedness in the region. Assessing this interregional initiative, the main objective of this paper is to shed light on the nature and functions of health interregionalism between Asia and Europe and its influence on regional health governance. It concludes that while in the specific context of the EU-ASEAN HPED program, health interregionalism had varied functions and a substantial influence on regional health governance, this initiative did not use the full potential that interregional health mechanism may provide to influence the development of another region or to promote the EU's specific actorness in regional and global health.
\end{abstract}

\section{Introduction}

Over the past decade, remarkable and sustainable progresses have been made in the Association of Southeast Asian Nations (ASEAN) region in the domain of communicable disease control. Thus, dracunculiasis and poliomyelitis have been eradicated; leprosy has been eliminated as a public health problem; significant improvements have been realized concerning HIV/AIDS, malaria, and tuberculosis morbidity and mortality; and in general, communicable disease mortality rate declined in all ASEAN Member States (AMS) (Kumaresan and Huikuri 2015).

Vincent Rollet

vincent.rollet59@gmail.com

1 Wenzao Ursuline University, Kaohsiung (TAIWAN)/French Centre for Research on Contemporary China (CEFC), 900 Mintsu 1st Road, Kaohsiung 807, Taiwan, ROC 
Nevertheless, communicable diseases remain an important public health issue in the region. It is notably the case of diseases that are naturally transmissible from vertebrate animals to humans (i.e., zoonoses) such as avian influenza, rabies, SARS, dengue fever, or foot and mouth disease (FMD) (Bordier and Roger 2013).

In December 2009, within the framework of its Regional Programming for Asia (2007-2013), the European Union (EU) launched a Regional Program on Highly Pathogenic and Emerging Diseases (HPED) in Asia. This 4-year interregional cooperation initiative aimed at enabling ASEAN to control zoonoses and to improve pandemic preparedness in the region. As this program is so far the only EU-ASEAN interregional initiative in the domain of communicable disease control and one of the few health-related projects between both regions, it represents a unique case study to appreciate an often-neglected dimension of EU-ASEAN relations as well as of global health governance, namely, health interregionalism.

The main objective of this paper is to shed light on health interregionalism between Asia and Europe and its influence on regional health governance. After having recalled that the EU is involved in the ASEAN region to support the fight against zoonoses for more than 20 years and that ASEAN did not wait the EU HPED program in Asia to develop and launch a regional response to zoonoses, this article uses an analytical framework inspired by the current academic debate concerning the functions of interregionalism to highlight the different roles of EU-ASEAN health interregionalism in the context of the EU HPED program in Asia.

\section{Assessing the role of EU-ASEAN health interregionalism: an analytical framework}

The recent academic debate about the functional role of interregionalism is full of insight in order to develop an analytical framework pertinent to appreciate the role of health interregionalism. Indeed, from this debate, it is possible to identify the following six main functions of interregionalism: institution building, regional integrator, multilateral utility, collective identity building, norm transmission, and balancing.

\section{Institution building}

A functional role of interregionalism, notably envisaged by the institutionalist approach, is its aptitude of institution building at the interregional level (Rüland 2008 , p. 302). Indeed, interregionalism has been often considered as representing a new level of governance situated between the global and regional levels and symbolized by interregional institutions and subsidiary institutions (dialogues, summits, forums, networks,...), whose main purpose is to facilitate substantial cooperation between two regions (Doidge 2004, p. 45). Consequently, to inquire into the institution-building function of interregionalism between ASEAN and the EU in the domain of health will consist, first, to appreciate if such interregionalism has created a new level of health governance between both regions and, secondly, to identify the beneficial role such new institutions or mechanisms might played in terms of cooperation between Asia and Europe. 


\section{Regional integrator}

Interregionalism has also been presented as a mechanism able to strengthen processes of regional integration. According to this hypothesis which resides in the formula "regionalism through interregionalism" (Hanggi 2003, p. 209), interregional interactions enhance regional integration in two principal ways.

First, by requiring a greater regional coordination from both regions involved, interregionalism encourages more frequent meetings between countries of each region in order to prepare interregional meetings, as well as, stimulates a greater transparency, rationalization, and predictability within the region and, occasionally, the establishment of specific regional entities to deal with such interregional interaction. In this context, regional coherence is improved, and therefore, regional integration is enhanced. This function of "regional integrator" (Maull and Tanaka 1997) has been confirmed in the context of Asia-Europe Meeting (ASEM), where within the framework of ASEM preparatory meeting, North-East Asian and South-East Asian country members had to meet and coordinate their position in order to work as a coherent group towards European members (Hanggi 2003, pp. 209-211).

The second way interregionalism can strengthen regional integration is when a region play the role of "external federator" (Santander 2008, p. 38) or in other words, when a region contributes through its actions towards another region to the enhancement of the integration process of that latter. Such function of interregionalism has been especially envisaged in the context of the EU's regional integration support to other regions, especially because the EU is today the only region implementing interregional programs with such objective. However, the implication of such initiatives on regional integration has been appreciated differently. Thus, if the impact of the EU's ASEAN Regional Integration Support (ARISE) and the ASEAN-EU Program for Regional Integration Support (APRIS) on ASEAN regional integration has been in general considered by EU and ASEAN officials as significant in different domains (standards harmonization, intellectual property rights,...) (European Commission 2009), some scholars have been more reserved and ask for scientific evaluation of such influence (Jetschke 2013, pp. 231-232).

Accordingly, a way to appreciate the existence of an integrative function of health interregionalism is to verify first whether EU-ASEAN health interregionalism provokes more frequent regional meetings between country members of the regions involved and, in turn, if it brings greater transparency, rationalization, and predictability of regional health governance. Furthermore, it should be appreciated if such interregionalism generates regional health institutions able to strengthen regional health governance but also if interregional health interactions between ASEAN and EU benefit to the regional harmonization on health-related issues.

\section{Collective identity building}

Interregionalism has been also granted by constructivist scholars with the capacity to enhance collective identity of the regions involved. Such function may be a direct consequence expected by an external federator engaged in interregional relations but also involuntary, when it emerges from the progressive awareness by a region of its own collective identity (Gilson 2002; Manea 2008). Fostering again the idea of regionalism through interregionalism, it has been argued that by being exposed to 
similarities and differences of another region, by trying to find recognition as a regional entity, or by aiming to reach regional cooperation and coherence in order to speak with one voice, a region involved in interregional interactions actually strengthens its "regional awareness" (Gilson 2005, pp. 309-310). While such function has been considered as too ambitious by some scholars (Santini et al. 2014, p. 78), others believed that interregionalism played such role (Doidge 2004, p. 51; Maull and Okfen 2008, p. 230; Manea 2008, p. 392).

Lastly, while in general, most substantial evidence on the role of interregionalism in collective identity building concerns the enhancement of identities within regions, it has been also argued that such function may occur across regions. Indeed, representing a unique dynamic for regions to recognize and express their shared values, interregionalism has been considered as able to encourage the emergence of interregional identity (Valle 2008, p. 20).

Having this in mind, the function of collective identity building of ASEAN-EU health interregionalism will be appreciated in the light of its capacity to stimulate or enhance the expression of a regional collective identity and/or to nourish the emergence of an interregional identity through health cooperation.

\section{Normative channel}

Recent studies have shed light on the capacity of interregionalism to act as norm transmitter from one region to another. ${ }^{1}$ Such diffusion of regulatory, cooperative, institutional, or political norms, among others, has been so far explained in two main different ways (Rüland 2014).

First, as a process of isomorphism when, in the context of interregional relations, one regional organization accepts and internalized norms coming from the other region by imitation, notably because the region is considered as an advanced model of integration but also because it brings prestige, recognition, and respectability (Bicchi 2006; Jetschke 2009).

But, norm diffusion also occurs when, in the context of its interregional relations, a region succeeds in persuading another region to change its own norms and to accept foreign norms. Being the more active regional actor in terms of norm diffusion, the majority of the recent studies have focused on the EU to show how it aims - and sometimes succeed - to diffuse the idea of regional integration to other regions through different mechanisms and instruments (Borzel and Risse 2009) and especially how it has promoted economic integration, institutionalization, and political norms to ASEAN (Allison 2015). For the EU, it has then been more a question of convincing another region for accepting particular set of norms and values than the result of imposed conditionality accompanied by material incentives (Rüland 2014, p. 28). On the recipient's side, acceptation and internalization of such norms deeply depend on the perception it has about the EU as an actor as well as on its consideration of EU's regionalism experience as relevant for its own regional integration (Allison 2015).

Being used by a region as a way to influence the behavior of another region by structuring a situation in such a way that the latter makes choices and defines interests in alignment with those of the influent region, interregionalism represents in that case

\footnotetext{
${ }^{1}$ See Special Issue "Rising" Asia and "Normative Power Europe": New Perspectives in the Dialogue on Norms and Values (2015), Asia Europe Journal, September, Issue 3: 233-360.
} 
an instrument of "soft power" (Rüland 2014, pp. 27-30). However, in both contextsunintentional or intentional norm diffusion - it is important to underline that the norm recipient seldom accepts them as a whole but actually often tends to adjust them to the regional situation and that rejection of norms often occurs.

To confirm or not the function of normative transmitter of health interregionalism, this study will observe if EU-ASEAN interactions in the domain of health facilitate the transmission of health-related norms from the EU to ASEAN and if these norms are progressively internalized, adapted, or rejected.

\section{Multilateral utility}

Considering that within the context of a close partnership with multilateral institutions, interregional forums were able to contribute to the response brought by the international community to global issues, the postulate of a "multilateral utility" of internationalism progressively emerged (Dent 2008, p. 121).

First, interregionalism has been envisaged as a tool to engage regional power into multilateral processes. Besides, in the context of a complexification of multilateral negotiations within global forums, the great heterogeneity of interests, and a prodigious technicity of most global issues, interregionalism has been also presented as able to play the role of a clearing house able to organize and rationalize points of views of actors belonging to different regions before global negotiations (Rüland 2008, p. 306). Interregionalism would help then global negotiations to save time; to avoid blockages at the beginning of the processes; and consequently, to increase efficiency (Dent 2008).

Furthermore, the multilateral utility of interregionalism has been also considered by scholars as manifest when interregional relations influence multilateral governance. Either because interregionalism enables the emergence of a common position among two regions on a specific subject which then plays an influential role on the global negotiation process and its results or because interregionalism is used by regional grouping or states as an agenda-setting instrument for advancing policies or themes unnoticed at the global level (Rüland 2008, p. 307). On such multilateral influence of interregionalism, opinions remains however mixed among scholars and evidence rather scarce (Dent 2008; Yeo 2008, p. 14; Maull and Okfen 2008).

In this context, the multilateral utility of EU-ASEAN health interregionalism will be appreciated in reference to its capacity to facilitate the engagement of a regional power within multilateral health governance and to help rationalize the positions of the two regions on a specific health issue before being defended during multilateral negotiations. Furthermore, its ability to foster the emergence of a common interregional position on a specific health issue that plays an influential role on the global health negotiation process or its capacity to represent an instrument used by regional grouping or states to advance specific health policies or themes at the global level will be also assessed.

\section{Balancing relationships}

Balancing is certainly the function of interregionalism that received the greater unanimity among scholars. However, it has been neither considered nor illustrated the same way.

In reference to the realist school of international relations, some scholars have presented interregionalism as an important tool of power balancing used to reach 
equilibrium in power relations between states/groups of states and a dominant regional power (Dent 1998). Most observers agree to say that in the context of Europe-Asia relationship, such balancing function is far from being confirmed despite recent attempts of interregional cooperation in the domain of traditional security (Maul and Okfen 2006, p. 221; Dosch 2011, p. 150).

For their part, institutionalist scholars have granted interregionalism a function of institutional balancing. Such functionality appears when interregionalism has been motivated by the perception of an imbalance between two regions (Rüland 2008, p. 300). This imbalance might be economic, political, or societal. These scholars consider institutional balancing as an explanatory factor of interregionalism between North America, the European Union, and Asia (Gilson 2005; Doan 2012).

Finally, from the constructivist approach, a new aspect of the balancing function of interregionalism that is soft power balancing emerged (Rüland 2014, pp. 27-30). As it was underlined earlier, one of the main objectives of exporting norms is to structure a region in alignment with its own interest. However, many actors wish to have such influence, and it is in this context that soft power balancing is envisaged.

To appreciate if the EU-ASEAN health interregionalism possesses any balancing function, this study will observe first if by creating new health-related institutions, such interregionalism helps to re-balance EU-ASEAN interactions comparatively to ASEAN interactions with other actors in the same domain (institutional balancing). Furthermore, such function will be also appreciated in the light of the ability of EU-ASEAN health interregionalism to enhance the EU's normative influence towards ASEAN, in particular comparatively to the influence that other actors have towards ASEAN (soft power balancing).

\section{EU and ASEAN's involvement in the fight against zoonoses in Asia}

\section{From bilateral to interregional interactions}

Since early 1990s, the EU is involved in the field of animal health in the ASEAN region exclusively in the form of bilateral assistance provided to several ASEAN countries to support their responses to zoonoses. Such choice of bilateralism was confirmed in the EC strategic paper "European Commission (2001)," which considered that bilateral cooperation with individual countries would support the achievement of most ASEAN strategic objectives (European Commission 2001).

However, the EC's strategy on "European Commission (2003)" offered the opportunity to health interactions between the EU and the ASEAN region to include an interregional level of cooperation (European Commission 2003). Indeed, in this new document whose main objective was to support the ASEAN vision of achieving the ASEAN community by 2020 , and consequently, to support ASEAN integration and region-to-region dialogue, EC recognized that, simultaneously to bilateral channels, its general assistance to ASEAN should also be implemented with a regional approach. According to the EC, such approach made sense when it satisfies the "two-way valueadded test," i.e., when the EC's regional support possesses a significant added value compared to EC's bilateral cooperation with individual ASEAN country and secondly, when the EU can provide particular added value on specific topics identified by ASEAN as priority (European Commission 2003, p. 19). 
The EC's intention to provide support to the regional response to zoonoses in Asia was first expressed during the International Conference on Avian Flu held in Beijing in January 2006. Indeed, in the final declaration of this event, the EC promised to support regional efforts to develop and enhance capacities and infrastructures in the domain of human and animal health. EC's regional approach to the fight against zoonoses in Asia was then confirmed in its new "Regional Strategy of the EU for Asia (2007-2013)," where the support to regional control of avian influenza and highly pathogenic and emerging diseases was presented as the second of the three priority areas of the EU in the region (European Commission 2007).

Then, the nature of the EU's support to the regional response to the fight against avian influenza in Asia also took shape and evolved during the Inter-Ministerial Conferences on Avian Pandemic Influenza (IMCAPI). While IMCAPI confirmed that regional organizations must be considered as an important actor of the fight against avian influenza, which, in turn, filled out the EU's idea to launch an EU-ASEAN initiative to face this health issue, the reflection about the nature of this project also evolved significantly once the "One Health" approach ${ }^{2}$ was put at the global agenda during the 2007 IMCAPI in New Delhi. Indeed, endorsing this approach that promotes the cooperation between the actors of animal health (veterinarians, farmers,...) and of human health (doctors, nurses,...) in order to bring a coordinated response to the whole threats emerging from the human-animal-ecosystem interface, the EU decided then to enlarge the coverage of its forthcoming program to include additional highly pathogenic diseases and not only avian influenza. In this context, EC decided to collaborate with Food and Agricultural Organization of the United Nations (FAO), World Organization for Animal Health (OIE), and the World Health Organization (WHO), which had already cooperated together notably for the launch of the Global FrameworkTransboundary Animal Diseases (GF-TADs). Then, in July 2008, the EU's Regional Program against Highly Pathogenic Emerging Diseases in Asia (HPED program) was presented by the EC to OIE, FAO, and WHO as well as ASEAN representatives and was then approved. ${ }^{3}$

\section{ASEAN regional health cooperation against zoonoses}

ASEAN did not wait the EU's HPED program to launch regional initiatives to respond to emerging zoonoses. Indeed, such regional determination to respond to these communicable diseases is confirmed in the "Healthy ASEAN 2020 Plan," which represents the regional vision guiding ASEAN's involvement in health since 2000, as well as in the "Roadmap for an ASEAN Community (2009-2015)," which proposed a Strategic framework on health and development (2010-2015) aimed at charting the direction for further ASEAN health integration. Furthermore, in order to move from words to action, ASEAN adopted regional action plans targeting HPEDs such as the "ASEAN Multisector Pandemic Preparedness and Response Work Plan (2007-2010)" or the Regional strategy for the progressive eradication of highly pathogenic avian influenza (2008-2010).

\footnotetext{
${ }^{2}$ The concept of "One Health" is an approach that calls for increased multidisciplinary and intersectoral cooperation to address diseases that emerge at the human-animal-ecosystem interface and that pose a threat to animal and human health.

${ }^{3}$ Interview with EU Official, Europaid, Brussels, 20 July 2014.
} 
Besides, three technical groups-ASEAN Expert Group on Communicable Diseases (AEGCD), the ASEAN Working Group on Pandemic Preparedness and Response (AWGPPR), and the ASEAN Sectoral Working Group on Livestock (ASWGL) - have been entrusted to support AMS to implement regional policies and strategies.

Thanks to the support of the Australian government, since 2005, ASEAN possesses ASEAN + 3 Partnership Laboratories (APL), which strengthen the regional monitoring and diagnosis of zoonoses as well as an ASEAN + 3 Surveillance and Information Network targeting some zoonoses. In 2006, ASEAN created a Regional Trust Fund for Animal Health to finance ASEAN animal health projects supporting the regional coordination for control and eradication of FMD, highly pathogenic avian influenza (HPAI), and other communicable diseases. In 2007 , in order to allow official representatives of AMS to exchange information related to animal diseases in real time, ASEAN launched the ASEAN Regional Animal Health Information System (ARAHIS), which is directly linked to the OIE World Animal Health Information System (WAHIS).

Despite these regional efforts, challenges to reduce the burden of zoonoses in the ASEAN region were however still numerous. Thus, the success in controlling zoonotic diseases in the region was then mainly jeopardized by the weakness of medical and veterinary institutions to detect and respond to those pathogens and to contain infections but also by difficulties to implement preventive measures to limit socio-cultural practices and to improve socio-economic and environmental factors that facilitate the occurrence of zoonoses. Furthermore, at that time, a very limited regional and international attention to neglected zoonotic diseases, a significant lack of scientific knowledge about the route of regional transmission and the real status of zoonoses in the region, and a lack of an efficient surveillance and control network and the absence of a rational allocation of resources prevented the ASEAN region to leave its status of "hotbed for the endemization of zoonotic diseases" (Bordier and Roger 2013, p. 43).

\section{Governance and modalities of the EU HPED program}

In this context, the EU's HPED program, launched in December 2009 with a total budget of 22.6 million euros mainly financed by the EU (84\%), had three main purposes. First, to strengthen the capacities of ASEAN in order to better monitor, control, and respond to emerging animal and human diseases. The following three main initiatives to be implemented by the WHO and FAO were then proposed: first, the creation of a Regional Support Unit (RSU) within ASEAN aiming at promoting regional cooperation against HPED; secondly, the establishment of an Epidemiology Regional Network affiliated to ASEAN to enhance the regional capacity to understand the epidemiology of HPED and then be able to decide and implement appropriated measures; and finally, the development of a Regional Network of Laboratories affiliated to ASEAN in order to coordinate the work of national laboratories and to provide technical assistance to improve their capacities of HPED diagnostic.

The second purpose of the EU HPED program in Asia was to strengthen ASEAN veterinarian services in the region. The program proposed then to launch a regional evaluation of veterinarian service performances within ASEAN according to a model developed by OIE with the main objective to obtain an updated map of the efficiency of ASEAN veterinarian services useful to proposed adequate measures to ameliorate the 
situation. It was also proposed to organize regional meetings and trainings for ASEAN veterinarians and to create a regional bank for HPED vaccines.

The third objective was to strengthen surveillance and response capacities in member countries to prevent, detect, notify, and react to HPEDs in reference to the framework of WHO Asia-Pacific Strategy for Emerging Diseases (APSED), which highlights the prevention and control of HPEDs, including zoonoses, as one of the priority program areas.

Interestingly, if we put aside the WHO component which is bilateral by nature, the EU HPED initiative actually covers two types of interregionalism. First, "pure interregionalism" which refers to the process, whereby two regions interact through their respective regional organizations. It is indeed the case when in the context of the FAO and OIE components, the EU aims at strengthening ASEAN capacities to HPEDs through the establishment of a RSU within ASEAN, an ASEAN Regional Epidemiological Network and an ASEAN Regional Network of Laboratories. Simultaneously, the program is also an illustration of "hybrid interregionalism," which refers to a framework where one regional organization interacts with a cluster of states which might have been involved in regional cooperative process but have not built together a formal regional organization. This is notably the case of the EU's support to the creation of Regional Banks for HPED Vaccines which target AMS; SAARC countries; and China, Mongolia, and North Korea together.

However, whether it is pure or hybrid interregionalism, one of the main specificities of the EU HPED program in Asia is certainly that it is an illustration of "proxy interregionalism." Indeed, while meeting once a year with its ASEAN counterparts during the HPED steering committee, the EU representatives did not interact directly with its ASEAN colleagues out of these committees. ${ }^{4}$ In other terms, while the EU was the main initiator and financial supporter of this interregional health initiative, direct, and regular interactions with ASEAN, its health-related technical groups and the ministries of health of the AMS were fully delegated to FAO, OIE, and WHO regional offices which worked with these regional and national partners to coordinate and implement the HPED program. Furthermore, unlike what we observe with APRIS or ARISE initiatives, no official or expert from the European Commission was based in Jakarta to deal with the HPED program on a day-to-day basis. Such management of the EU HPED program makes it a rather unique type of interregionalism.

\section{Functions of EU's support to ASEAN response to HPED}

In the light of the theoretical framework developed earlier, we observed that the EU HPED program has played four main roles: (1) enhancing regional health governance within ASEAN (regional integrator), (2) diffusing international norms aimed at strengthening global health governance (normative channel), (3) confirming EU actorness in global health governance (institutional balancing), and (4) enhancing ASEAN's engagement in health multilateralism and enabling common interregional position (multilateral utility).

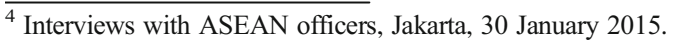




\section{Enhancing regional health integration}

The EU HPED initiative played a significant role in terms of regional health integration in ASEAN. One of the main illustrations of such a role is the establishment of an ASEAN RSU on Animal Health and Zoonoses in 2010. While since 2008, ASEAN had worked to develop such regional structure with the support of the Asian Development Bank (ADB), Australian Agency for International Development (AusAid), FAO, and OIE, the EU's financial support came at the right moment and was decisive in providing ASEAN Secretariat with the material and human capacities to establish it. ${ }^{5}$ Simultaneously, the EU's support was also determinant to create RSU-affiliated working groups-ASEAN Veterinary Epidemiology Framework, ASEAN ad hoc Communication Group for Livestock, and ASEAN ad hoc Laboratory Group - which have elaborated Regional Strategic Frameworks (RSF) with AMS and international partners. In general, when they are asked about the role played by the EU program in terms of strengthening cooperation in the field of zoonotic management in the region, ASEAN and FAO officers confirm that the establishment of such coordination entity within ASEAN would not have been possible without the EU's multiple-year support, which allows them to plan their activities in the long term. Thus, they often consider the program as an important leverage for better coordination and harmonization in zoonotic control in the region. Furthermore, ASEAN officers and AMS health experts notably underlined the constructive impact of the workshops/trainings supported by the EU HPED program in terms of coordination, harmonization, and transparency. ${ }^{6}$

Thus, by supporting directly a better coordination of AMS in the domain of zoonotic diseases and by paving the way for the establishment of the ASEAN Coordination Centre for Animal Health and Zoonoses (ACCAHZ) in 2017 which, as a continuation of the ASEAN RSU, will represent the most concrete achievement of the strengthening process of ASEAN regional capacities in the domain of zoonotic diseases management, it seems not exaggerated to say that in the domain of zoonotic diseases, the EU played the role of external federator towards ASEAN.

A second illustration of such influence can be observed through its support to the establishment of regional vaccine banks in the ASEAN region. Indeed, based on its experience in Africa where it funded an OIE Regional Vaccine Bank for Avian Influenza, the EU provided financial resources to establish in Asia a Regional Antigen/Vaccine Bank for FMD in 2011 as well as a Regional Vaccine Bank for Rabies in 2012. The main objective was to rapidly provide eligible countries with an emergency stock of vaccines to vaccinate animal populations at risk and then to protect humans against negative consequences on food security (FMD) or for being infected (rabies). While the EU had also planned to support such mechanism against avian influenza, the fact that some ASEAN countries had already their own support to buy their vaccines (Vietnam); that some AMS refused to use the vaccine (Indonesia); and that in order to eliminate avian influenza, it is easier and cheaper to eliminate birds than to use vaccination, the bank was not established. ${ }^{7}$ Once again, the EU financial support to such banks was much needed and certainly made

\footnotetext{
5 Idem.

${ }^{6}$ Interviews with ASEAN officers, Jakarta, 30 January 2015; Interview (Skype) with FAO officer, 20 August 2015.

${ }^{7}$ Interview with OIE officer, Bangkok, 27 January 2015.
} 
the difference. For OIE which did not have enough funds to buy vaccines for the alreadyestablished FMD program, the financial support provided by the EU built up the FMD program and made possible for the OIE to develop a second bank dedicated to rabies. ${ }^{8}$ So far, the banks have been able to provide vaccine doses to Lao PDR, Myanmar, and Cambodia to respond to an outbreak of FMD in 2013 and to Lao PDR, Vietnam, the Philippines, and Indonesia for dog vaccination against rabies in 2015.

Confirming the EU's role of external federator towards ASEAN in this domain, ASEAN officers consider that both banks are concrete initiatives supporting the ASEAN Roadmap for an ASEAN Community, especially objectives expressed in the AEC Blueprint (A7, pp. 38-40) and the ASCC Blueprint (B3, B4) and represent significant instruments for the implementation of the ASEAN Call for Action towards the Elimination of Rabies (2008) and the ASEAN Strategic Plan of Action on Food Security (2009).

However, while the EU HPED program undoubtedly strengthened regional integration, once it has been completed, the EU did not guarantee the sustainability of the mechanisms it supported initially. Indeed, considering the HPED initiative as "seed money" $" 10$ needed to support disease control in the region on a limited time, the EU did not pursue its financial support beyond that period. In this context, implementing partners and ASEAN had to find alternative financial supports to pursue the functioning of the regional mechanisms built with the European support. Aware of such situation, since the beginning of the program, and having decided to adopt a multidonor approach, they received financial support from Australia, New Zealand, and Republic of Korea to support the FMD regional vaccine bank as well as from Australia, Singapore, and WHO to fund the Regional Rabies Vaccine Bank. Simultaneously, France and other European countries financed bilaterally the delivery of rabies vaccines to Thailand and Indonesia.

${ }^{11}$ While regional banks are deeply reliant on the good will of the donors, the importance to reach financial sustainability is also central for the operationalization of the ACCAHZ in 2017. Nevertheless, to avoid such dependency, the Preparatory Senior Officials Meeting of the 35th ASEAN Ministers on Agriculture and Forestry (AMAF) held in Kuala Lumpur (23-24 September 2013) agreed to provide annual contribution of funds from AMS to support annual core operational costs of ACCAHZ. If such decision must be considered as the best viable option for the sustainability of this new regional institution, it also represents a further commitment from ASEAN to address zoonoses regionally and to strengthen regional health integration.

\section{Diffusing international norms aimed at strengthening global health governance}

A way the EU HPED program has strengthened global health governance is through the diffusion of globally accepted health norms towards ASEAN. Indeed, by facilitating the compliance of ASEAN and AMS to these international norms, the EU supported the national implementation of essential instruments for an efficient global response against transnational health issues.

\footnotetext{
${ }^{8}$ Idem.

${ }^{9}$ Interviews with ASEAN officers, Jakarta, 30 January 2015.

${ }^{10}$ Interview with EU Official, Europaid, Brussels, 20 July 2014.

${ }^{11}$ Interviews with ASEAN officers, Jakarta, 30 January 2015; Interview with OIE officer, Bangkok, 27 January 2015.
} 
The role of normative channel played by the program is revealed first through its support to the regional and national compliance to the OIE Terrestrial Animal Health Code which sets out standards for the improvement of animal health and welfare and veterinary health worldwide, as well as to the WHO International Health Regulations (IHR), which is an international legal instrument that is binding on 196 countries across the globe with the aim at preventing and responding to acute public health risks that have the potential to cross borders and threaten people worldwide. Indeed, by holding training, workshops, and other related activities that support the enhancement of the AMS veterinary services and health systems in reference to OIE code and WHO regulations, the EU program has played an instrumental role for the diffusion of these international standards within ASEAN, which in turn reinforces the efficiency of global health governance.

Norm transmission also occurred through the diffusion of the One Health $(\mathrm{OH})$ approach, which is today encouraged globally (European Commission 2011). Within the framework of its "One Health Program in Asia" (EuropeAid/133708/C/ACT/Multi), the EU has made the diffusion and the implementation of such approach a priority in Asia and, consequently, a core objective of the EU HPED initiative which then represents an additional channel to transmit this globally accepted approach to ASEAN (European Commission 2011; European Commission 2013, p. 13). The diffusion of the $\mathrm{OH}$ approach was facilitated by the presence of a FAO expert, hired by the EU project, and based at the ASEAN Secretariat in Jakarta. ${ }^{12}$ Indeed, this expert succeeded in convincing ASEC to organize the first joint meeting between the ASWGL and the AEGCD in 2013 in order to work on an animal and human regional strategy on rabies elimination. As a result of this cooperation, in 2015, ASEC launched the ASEAN rabies elimination strategy which has been deeply influenced by the $\mathrm{OH}$ approach and consequently described as "an integrated One Health approach that brings together the necessary socio-cultural, technical, organizational, and political pillars to address this challenge" (ASEAN 2015, p. 11). The transmission of the $\mathrm{OH}$ approach also occurred during workshops and trainings supported by the EU program and dedicated to ASEAN national health officers, during which OIE officers promoted the $\mathrm{OH}$ approach. ${ }^{13}$ Interviews with trainees confirmed the use of OIE standards and guidelines related to the $\mathrm{OH}$ approach in their daily work ${ }^{14}$.

While the involvement of numerous actors and platforms in the promotion of OIE code, WHO IHR, and the $\mathrm{OH}$ approach towards ASEAN makes rather challenging the identification of the level of influence of the EU program on such norm transmission, it is not exaggerated to say that the EU HPED program participated to the diffusion of these globally accepted health norms whose the implementation at the regional and national levels is a key element of the enhancement of global health governance.

\section{Confirming EU actorness in global health governance}

To understand the role played by the EU HPED program in Asia in confirming EU's actorness in global health governance, it is important to appreciate the general context of international cooperation with ASEAN on zoonoses before December 2009. First, at that time, several international organizations - intergovernmental (OIE, WHO, FAO,

\footnotetext{
${ }^{12}$ Interview (Skype) with FAO officer, 20 August 2015.

${ }^{13}$ Interview with OIE officer, Bangkok, 27 January 2015.

${ }^{14}$ Interviews with two participants to this training, Bangkok, 27 January 2015, and Jakarta, 29 January 2015.
} 
Asian Development Bank) and non-governmental (Rockefeller Foundation) - as well as countries (France, UK, Canada, Japan, USA, Australia) were cooperating with ASEAN and AMS to deal with zoonoses in the region. These actors, also considered as main actors of global health governance, were implementing and supporting significant and highly visible initiatives against zoonotic diseases, such as SARS or avian influenza, which had become at that time an urgent concern for the international community.

Furthermore, while there was no interregional initiatives involving ASEAN in such domain, APEC - a transregional organization - in which all ASEAN countries are members and where the USA and Australia exercise a perceptible influence was also very active in this field.

In other words, comparatively speaking, with few bilateral assistant programs targeting a small number of ASEAN countries, the EU's involvement in the support to ASEAN region against zoonoses was rather limited at that time. And this, despite the fact that during the International Conference on Avian Influenza held in Beijing in January 2006, the EC expressed its intention to strengthen its support to the regional response to zoonoses in Asia, that the EU Health Strategy (2008-2013) called for strengthening the EU's voice in global health, and finally, while since 2008, the EC was working on a strategic document related to the EU's role in global health"Communication on the EU Role in Global Health" - which granted the EU with a leading role in global health (Rollet and Chang 2013). The quasi-absence of the EU in the fight against zoonoses in the ASEAN region appeared then as a contradiction to its expectation of being a global health actor. In this context, the HPED program represented for the EU a way to fill the gap between its role expectation in global health and its concrete involvement in the ASEAN region (institutional balancing). By involving the EU in the ASEAN regional response against zoonoses, the interregional initiative helped then the EU to counterweight the long-term involvement of other main global health actors in the region, such as the USA, which actually had already strengthened its regional involvement in this domain at that time notably with its IDENTIFY project that aims at strengthening national veterinary laboratory capacities in the region. ${ }^{15}$

However, no sign of soft power balancing can be detected. Indeed, while approaches might differ between the EU and other supportive countries when it comes to health capacity strengthening, animal health regulation, or "One Health approach" implementation, the fact that the EU was more in a position to support OIE, FAO, and WHO, than directly involved with ASEAN (proxy interregionalism), did not allow neither specific EU approaches or values nor the EU regional experience in the domain of zoonoses prevention and control to be shared with ASEAN. Indeed, as mentioned earlier, if norm transmission between the EU and ASEAN obviously occurred within the framework of the EU HPED program, the diffused norms were globally shared norms, not EU-specific norms. Interviews with officers from implementing institutions and international aid agencies also confirm such reality as, in general, unlike what they observe in other domains such as animal welfare standards or food safety, they did not see any influence of norms and values specific to the EU neither an intention of the EU to be considered as a model in the context of the HPED program. ${ }^{16}$

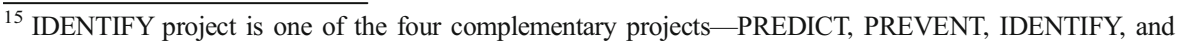
RESPOND projects - implemented by USAID within the framework of the US Emerging Pandemic Threats Program launched in 2009 to strengthen capacities in developing countries to prevent, detect, and control dangerous pathogens from animals before they can become significant threats to human health.

${ }^{16}$ Interview with OIE officer, Bangkok, 27 January 2015; Interview with USAID officer, Bangkok, 26 January 2015; Interview (Skype) with FAO officer, 20 August 2015.
} 
Enhancing ASEAN's engagement in health multilateralism and enabling common interregional position

The EU HPED program possesses a certain multilateral utility. First, it has contributed to further the participation of ASEAN to the multilateral response to zoonoses in the region. While ASEAN was already involved within the Regional Steering Committee for Asia and the Pacific of the GF-TADs since its inception in 2005 and, in this respect, was already involved in health multilateralism at the regional level, the EU program offered to ASEAN an additional opportunity to work simultaneously and to cooperate with the main actors of the fight against zoonoses in the region. A further involvement in health multilateralism was notably materialized by its participation to the Steering Committee of the EU HPED Program, which represented an occasion for ASEAN to enhance its interactions with other members of the committee (FAO, OIE, WHO, SAARC, and the EU) as well as with its observers (AusAid, USAID, JICA, Secretariat of the Pacific Community (SPC), Australian and US agricultural ministers). As ASEAN officers underlined during interviews, through its participation to the EU HPED program, ASEAN enhanced its experience of cooperating with multiple actors under a similar health initiative. ${ }^{17}$

A second aspect of the multilateral utility of this program is tangible in its capacity to rationalize the position of ASEAN and EU on a specific health topic and then to facilitate the development of an interregional position to be defended at the global level. This is particularly the case of the creation of a global bank of vaccines for rabies. As we mentioned earlier, since a decade, in cooperation with OIE, the EU has supported the establishment of several regional vaccine banks in Africa as well as in Asia and then promoted such instrument as an efficient mechanism to control and eradicate HPEDs. The establishment of Regional Vaccine Banks for Rabies and FMD in Asia under the EU program and its positive achievements also helped ASEAN to be convinced about the importance of such instrument and to back the EU's support campaign to OIE for the establishment of a global vaccine bank for rabies. Indeed, interviews with EU and ASEAN officials confirm the EU and ASEAN plan to use the experience of the regional vaccine bank for rabies as a strong argument to support a global vaccine bank against these zoonoses during multilateral meetings such as the World Health Assembly (WHA) or the General Session of the OIE. ${ }^{18}$

Other expected functions of interregionalism, i.e., institution building and collective identity building, have not been confirmed so far or not directly linked with the EU program. Indeed, if the EU HPED program has certainly reinforced the cooperation between the EU and ASEAN, it did not create specific and sustainable interregional health institution/mechanism aimed at benefiting interregional health cooperation between both regions. The steering committee of the program was not "interregional" per se and actually disappeared once the program has been completed in 2014. As to the capacity for such interregional initiative to support collective identity building, according to the majority of the interviewees, if the

\footnotetext{
${ }^{17}$ Interviews with ASEAN officers, Jakarta, 30 January 2015.

${ }^{18}$ Interviews with ASEAN officers, Jakarta, 30 January 2015; Interview with EU Official, Europaid, Brussels, 20 July 2014.
} 
expression of a regional collective identity is tangible in the domain of rabies control notably since the launch of the ASEAN Strategy on Rabies Control, the EU program played limited role in such identity-building process as if it has supported the implementation of such regional strategy; it is the OIE and Australia that actually initiated and supported its development. ${ }^{19}$

\section{Conclusion}

The inquiry of the role of health interregionalism in the specific context of the EU-ASEAN HPED program reveals a substantial influence on regional health governance. Indeed, confirming its capacity to play a role of regional integrator, health interregionalism between the EU and ASEAN has strengthened ASEAN regional health governance, notably through the establishment of several regional mechanisms dealing with zoonoses. Furthermore, as a normative channel, such interregional health initiative has enhanced regional health governance through the diffusion and implementation of international health norms in the ASEAN region. Finally, representing an instrument of institutional balancing, it has also strengthened the EU's actorness in global and regional health governance, and, by confirming its multilateral utility, it has enhanced the ASEAN's engagement in health multilateralism and supported the development of common interregional position to be defended at the global level.

However, does such influence on regional and global health governance represents a specificity of health interregionalism? In fact, some aspects of such influence are specific to health interregionalism. It is notably the case of the strengthening of the EU's actorness in regional governance which could only be facilitated by health interregionalism which represents a unique opportunity for the EU to work at the regional level in cooperation with a regional organization. Health bilateralism would not allow such coverage. It is also the case of the emergence of an interregional position on a health issue which could only be the fruit of interregional interactions.

Simultaneously, other dimensions of this influence are not specific to interregionalism. Thus, the capacity of health interregionalism to support regional health integration certainly represents a specificity of interregionalism if, within the context of such interaction, a model of regional health integration is promoted by a region towards another. But if it is not the case-like in the context of the EU-ASEAN HPED initiative - there is no reason to think that a single country or an international organization would not be able to play the role of external federator.

Similarly, while the EU initiative has allowed the diffusion of globally accepted health norms to the ASEAN region, other actors, including USAID, UN agencies, and international NGOs, are also responsible for such normative transmission. It is then not a specificity of interregionalism. Actually, what could have been a specificity of health interregionalism in this context would have been the transmission of norms, standards,

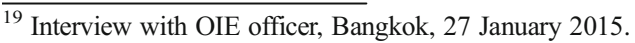


or values specific to the EU. However, in our case study, transmitted norms were globally accepted norms and not EU norms in particular.

For these reasons, it might be concluded that although able to have concrete effects on regional health governance, the EU-ASEAN HPED initiative did not use the full potential that interregional health mechanisms may provide to influence the development of another region or to promote the EU's specific actorness in regional and global health.

Acknowledgments Funding from the Taiwan's Ministry of Science and Technology (MOST) supported this research (Project MOST104-2410-H-160-001-MY2).

\section{References}

Allison L (2015) The EU, ASEAN and interregionalism. Regionalism Support and Norm Diffusion between the EU and ASEAN, Palgrave MacMillan

ASEAN (2015) ASEAN rabies elimination strategy, 16 September, Jakarta

Bicchi F (2006) Our size fits all. Normative power Europe and the Mediterranean. J Eur Publ Policy 13(2): 286-303

Bordier M, Roger F (2013) Zoonoses in South-East Asia: a regional burden, a global threat. Anim Health Res Rev 14(1):40-67

Borzel T, Risse T (2009) Diffusing (inter-) regionalism. The EU as a model of regional integration, working paper. N.7. Freie Universitat, Berlin, p 26

Dent C (1998) The ASEM: managing the new framework of the EU's economic relations with East Asia. Pac Aff 70(4):495-516

Dent C, Hanggi H et al (2008) The Asia-Europe Meeting (ASEM) process: beyond the triadic political economy? In: Interregionalism and international relations. Routledge, Abindgdon-New York, pp 113-127

Doan X.L (2012) Opportunities and challenges in EU-ASEAN trade relations », EU-Asia Centre, http://www. eu-asiacentre.eu/pub_details.php?pub_id=60. Accessed 31 Mar 2016.

Doidge M (2004) Interregionalism and regional actors: the EU-ASEAN example. In: Stokhof W, Van der Velde P, Hwee Y-L (eds) The Eurasian space: far more than two continents. Singapore, ISEAS, pp 38-55

Dosch J (2011) Europe and the Asia Pacific. Achievements of inter-regionalism. In: Connors M.K, Davison R, and Dosch J, The New Global Politics of Asia-Pacific, Routledge, New York, 2011 p.141-157

European Commission (2001) Europe and Asia: a strategic framework for enhanced partnership, COM/2001/ 0469 final, Brussels

European Commission (2003) A new partnership with Southeast Asia' COM (2003) 399/4. European Commission, Brussels

European Commission (2007) Regional strategy of the EU for Asia (2007-2013). European Commission, Brussels

European Commission (2009) Evaluation of EC co-operation with ASEAN: final report. European Commission, Brussels

European Commission (2011) Asia-Europe meeting. Implementation of the one health approach in Asia and Europe. European Commission, Brussels

European Commission (2013) EU HPED Programme, 4th Steering Committee Meeting-Summary Report, Tokyo, 16 July

Gilson J (2002) Asia meets Europe: interregionalism and the Asia-Europe meeting. Edward Elgar, Cheltenham

Gilson J (2005) New interregionalism? The EU and East Asia. European Integration, Vol.27, N.3, September 2005, pp. 307-326

Hanggi H (2003) Regionalism through interregionalism: East Asia and ASEM. In: Liu F-K, Régnier P (eds) Regionalism in East Asia: paradigm shifting? Curzon, London, Routledge, pp 197-219

Jetschke A (2009) Institutionalizing ASEAN: celebrating Europe through network governance. Camb Rev Int Relat 22(3):407-426 
Jetschke A (2013) Regional integration support by the EU in Asia: aims and prospects. In: Christiansen T, Kirchner E, Murray P (eds) The Palgrave Handbook of EU-Asia Relations. Palgrave Macmillan, pp 226-243

Kumaresan J, Huikuri S (2015) Strengthening regional cooperation, coordination, and response to health concerns in the ASEAN region: status, challenges, and ways forward. ERIA Discussion Paper 2015-60

Manea MG (2008) Human rights and the interregional dialogue between Asia and Europe: ASEAN-EU relations and ASEM. Pac Rev 21(3):369-396

Maull HW, Tanaka A (1997) The geopolitical dimension. In: The rationale and common agenda for AsiaEurope cooperation, CAEC task force reports. Council for Asia-Europe Cooperation, Tokyo/London

Maul HW, Okfen N (2006) Comparing interregionalism. The Asia-Pacific Economic Cooperation (APEC) and the Asia-Europe Meeting (ASEM). In: Hänggi H, Roloff R, Rüland J (eds) Interregionalism and international relations. Routledge, New York, pp 217-233

Maull H-W, Okfen N (2008) The Asia-Pacific Economic Cooperation (APEC) and the Asia-Europe Meeting (ASEM). In: Hanggi H (ed) Interregionalism and international relations. Routledge, Abindgdon-New York

Rollet V, Chang P (2013) Is the European Union a global health actor? An analysis of its capacities, involvement and challenges. Eur Foreign Aff Rev 18(3):309-328

Rüland J (2008) Interregionalism. An unfinished agenda. In: Hanggi H (ed) Interregionalism and international relations. Routledge, Abindgdon-New York, pp 295-313

Rüland J (2014) Interregionalism and international relations: reanimating an obsolescent research agenda? In: Baert F, Scaramagli T, Soderbaum F (eds) Intersecting interregionalism. Regions, global governance and the EU. Springer, London, pp 15-38

Santander S (2008) The European partnership with Mercosur: a relationship based on strategic and neo-liberal principles. In: Soderbaum F, Van Langenhove L (eds) The EU as a global player. Routledge, New York, pp 37-58

Santini RH et al (2014) Interregionalism: a security studies perspective. In: Baert F et al (eds) Intersecting interregionalism. Regions, global governance and the EU. Springer, London, pp 71-89

Valle VM (2008) Interregionalism: a case study of the European Union and Mercosur. GARNET working paper no: 51/08, July

Yeo LH (2008) Regionalism and interregionalism in ASEM. In: Hwee YL, Lopez I Vidal L, Regionalism and interregionalism in the ASEM context. Document CIDOB Asia 23, Barcelona, pp. 7-29 